\title{
Characterization of a Virus Infecting Citrus volkameriana with Citrus Leprosis-Like Symptoms
}

\author{
Michael J. Melzer, Diane M. Sether, Wayne B. Borth, and John S. Hu
}

Plant and Environmental Protection Sciences, University of Hawaii, 3190 Maile Way, St. John 310, Honolulu 96822. Accepted for publication 4 September 2011.

\begin{abstract}
Melzer, M. J., Sether, D. M., Borth, W. B., and Hu, J. S. 2012. Characterization of a virus infecting Citrus volkameriana with citrus leprosis-like symptoms. Phytopathology 102:122-127.

A Citrus volkameriana tree displaying symptoms similar to citrus leprosis on its leaves and bark was found in Hawaii. Citrus leprosis virus $C$ (CiLV-C)-specific detection assays, however, were negative for all tissues tested. Short, bacilliform virus-like particles were observed by transmission electron microscopy in the cytoplasm of symptomatic leaves but not in healthy controls. Double-stranded (ds) RNAs $\approx 8$ and $3 \mathrm{kbp}$ in size were present in symptomatic leaf tissue but not in healthy controls. Excluding poly(A) tails, the largest molecule, RNA1, was 8,354 bp in length. The $\approx 3 \mathrm{kbp}$ dsRNA band was found to be composed of two

distinct molecules, RNA2 and RNA3, which were 3,169 and 3,113 bp, respectively. Phylogenetic analyses indicated that the RNA-dependent RNA polymerase (RdRp) domain located in RNA1 was most closely related to the RdRp domain of CiLV-C. A reverse-transcription polymerase chain reaction assay developed for the detection of this virus was used to screen nearby citrus trees as well as Hibiscus arnottianus plants with symptoms of hibiscus green spot, a disease associated with infection by Hibiscus green spot virus (HGSV). All nearby citrus trees tested negative with the assay; however, symptomatic $H$. arnottianus plants were positive. All three RNAs were present in symptomatic $H$. arnottianus and were $>98 \%$ identical to the RNAs isolated from C. volkameriana. We contend that the virus described in this study is HGSV, and propose that it be the type member of a new virus genus, Higrevirus.
\end{abstract}

Citrus leprosis is an economically important viral disease of citrus in the Americas. The disease occurs in many South and Central American countries, and is a major hindrance to citrus production in regions of Brazil and Argentina (1,8,24,25). In the early 1900s, citrus leprosis was responsible for heavy losses in Florida's citrus industry (15). The disease, however, began to subside by 1930, and was not observed in recent surveys of Florida and Texas citrus groves $(5,16)$. Citrus leprosis has not been reported in Hawaii.

Symptoms of citrus leprosis are most severe for sweet orange and mandarin varieties and include chlorotic lesions on leaves and fruit that often become brown with a necrotic center. Raised necrotic lesions that are rusty in color develop on twigs and often coalesce, causing the bark to slough (3). Citrus leprosis has been associated with two distinct, nonsystemic viruses that are transmitted by Brevipalpus mites $(1,4,24)$. The first are short rodshaped particles (35 to 40 by 120 to $130 \mathrm{~nm}$ ) found predominantly in the nuclei of infected cells (13). This virus, referred to as Citrus leprosis virus nuclear type (CiLV-N), has only been reported in a few locations $(8,13)$. The second are short bacilliform particles of 50 to 55 by 120 to 130 (and up to 300) nm that are found in the cytoplasm of infected cells (24). This virus, CiLV cytoplasmic type (CiLV-C), is the more common of the two viruses associated with citrus leprosis symptoms (1,24). CiLV-C has been completely sequenced and is the type member of the new viral genus Cilevirus $(2,19)$. It has a bipartite genome with the $\approx 8.7 \mathrm{~kb}$ RNA1 encoding a $286-\mathrm{kDa}$ polyprotein with methyl-

Corresponding author: J. S. Hu; E-mail address: johnhu@hawaii.edu

GenBank accession numbers: HQ852052, HQ852053, and HQ852054.

* The $\boldsymbol{e}$-Xtra logo stands for "electronic extra" and indicates that Figure 1 appears in color online.

http://dx.doi.org/10.1094/PHYTO-01-11-0013

(C) 2012 The American Phytopathological Society transferase, protease, helicase, and RNA-dependent RNA polymerase ( $\mathrm{RdRp}$ ) domains, and a 29-kDa protein of unknown function. The $\approx 5.0-\mathrm{kb}$ RNA2 encodes $15-$ and $61-\mathrm{kDa}$ proteins, a $32-\mathrm{kDa}$ protein with homology to viral movement proteins (MPs), and a 24-kDa protein (19).

Hibiscus green spot is a disease primarily observed in Hibiscus rosa-sinensis and was first described in Brazil but has also been observed throughout the Americas as well as in Hawaii and New Zealand $(12,14)$ (M. J. Melzer, unpublished data). The symptoms of hibiscus green spot are green or brownish spots or ringspots in senescent leaves. Similar to citrus leprosis, the disease is associated with Brevipalpus mite infestation and the presence of short bacilliform virus particles present in the cytoplasm $(12,14)$. Genetic data and specific assays for identification and detection of this virus, termed Hibiscus green spot virus (HGSV), have not been reported.

In 2009, symptoms similar to citrus leprosis were observed on twigs and leaves of a Citrus volkameriana (Ten. \& Pasq.) tree growing in Waimanalo, on the island of Oahu, Hawaii. The objective of this study was to determine whether CiLV-C is present in Hawaii and was responsible for the observed symptoms on citrus. Here, we report the absence of CiLV-C in symptomatic citrus and, instead, the identification and characterization of HGSV in symptomatic citrus and hibiscus.

\section{MATERIALS AND METHODS}

Virus source and symptomology. In 2002, a >20-year-old $C$. volkameriana tree growing at the Poamoho Research Station on the island of Oahu, Hawaii was propagated by air layering and transferred to the Waimanalo Research Station located in Waimanalo, Oahu, Hawaii, where it became established as tree WAI 1-1. Tree WAI 1-1 is infected by Citrus tristeza virus (CTV) (family Closteroviridae, genus Closterovirus) (21) and also has symptoms of woody gall, a putative viral disease of citrus for which a luteovirus has been implicated (6). In 2009, foliar symp- 
toms and raised circular lesions on twigs, similar to those found on citrus leprosis-affected trees, were also observed on tree WAI 1-1 (Fig. 1). Foliar symptoms were most prevalent during the coolest months of the year (i.e., December to March). Chlorotic or necrotic lesions on the fruit, which are other symptoms of citrus leprosis, were not observed on fruit that matured in 2009. No fruit were produced by this tree during the 2009-10 growing season.

Serological and molecular detection. A double-antibody sandwich indirect enzyme-linked immunosorbent assay (DASIELISA) using antibodies developed in rabbit (R27) and chicken (C30) against in vitro-expressed CiLV-C p29 protein was used to determine whether CiLV-C or a serologically related virus was present in tree WAI 1-1. Symptomatic and asymptomatic leaf, petiole, and bark tissue from WAI 1-1 and a healthy seedling control were macerated in 10 volumes of phosphate buffered saline with Tween (PBS-T) $(137 \mathrm{mM} \mathrm{NaCl}, 2.7 \mathrm{mM} \mathrm{KCl}, 10 \mathrm{mM}$ $\mathrm{Na}_{2} \mathrm{HPO}_{4}, 2 \mathrm{mM} \mathrm{KH} \mathrm{PO}_{4}$, and $0.1 \%$ Tween20, $\mathrm{pH}$ 7.4). The samples were centrifuged, and $100 \mu \mathrm{l}$ of supernatant was added to an Immulon 2 ELISA plate (Dynatech Laboratories, Chantilly, VA) coated with a 1:1000 dilution of the primary antibody R27 in coating buffer $\left(35 \mathrm{mM} \mathrm{NaHCO} 3,15 \mathrm{mM} \mathrm{Na}_{2} \mathrm{CO}_{3}\right.$, and $3 \mathrm{mM}$ $\mathrm{NaN}_{3}, \mathrm{pH}$ 9.6). After a 2-h incubation at $37^{\circ} \mathrm{C}$, the wells were washed with PBS-T and exposed to a $1: 1,000$ dilution of the secondary antibody, C30, in PBS-T for $2 \mathrm{~h}$ at $37^{\circ} \mathrm{C}$. After washing with PBS-T, the wells were exposed to anti-chicken IgY (immunoglobulin G) (whole molecule)-alkaline phosphatase antibody produced in rabbit (Sigma-Aldrich, St. Louis) diluted $1: 30,000$ in PBS-T containing polyvinylpyrrolidone $(2 \% \mathrm{wt} / \mathrm{vol})$ and bovine serum albumin $(0.2 \% \mathrm{wt} / \mathrm{vol})$. After washing in PBS-T, phosphatase substrate (Sigma) was added following the manufacturer's directions and color development was quantified at $405 \mathrm{~nm}$ with a Model 680 microplate reader (Bio-Rad Laboratories, Inc., Hercules, CA). Expressed CiLV-C p29 antigen was used as a positive control at 500- and 1,000-fold dilutions. R27, C30, and the expressed antigen were provided by R. F. Lee (U.S. Department of Agriculture-Agricultural Research Service, Riverside, CA).

A reverse-transcription polymerase chain (RT-PCR) assay was developed for the detection of HGSV. Citrus leaf tissue $(\approx 100 \mathrm{mg})$ was pulverized in liquid nitrogen and total nucleic acids (TNAs) were extracted as described by Stewart and Via (28), except that DIECA was omitted from the extraction buffer. First-strand cDNA synthesis was performed using 2 to $4 \mu$ of TNAs, random hexamers, and MMLV-RT (Promega Corp., Madison, WI) following the manufacturer's instructions. A $20-\mu$ l hot-start PCR was then performed on 1 to $2 \mu \mathrm{l}$ of the cDNA using primer sets MPF/MPR, RepF/RepR (18), or 896 (5'-GCGACGGGAAAAA TACTGAAG-3') and 897 (5'-CGCAGTCACAGACGTAAAC-3'), and $2 \times$ ImmoMix (Bioline, Randolph, MA) with the following cycling profile: 1 cycle of $95^{\circ} \mathrm{C}$ for $7 \mathrm{~min} ; 32$ cycles of $95^{\circ} \mathrm{C}$ for $30 \mathrm{~s}, 56^{\circ} \mathrm{C}$ for $30 \mathrm{~s}$, and $72^{\circ} \mathrm{C}$ for $30 \mathrm{~s}$; and 1 cycle of $72^{\circ} \mathrm{C}$ for $7 \mathrm{~min}$. Amplification products were resolved in a $2 \%$ agarose gel stained with ethidium bromide and visualized with UV light. Primer sets MPF/MPR and RepF/RepR target the putative MP gene (339-bp amplicon) and replicase protein gene (402-bp amplicon) of CiLV-C, respectively (18). Based on the sequence information obtained in this study, primer set 896/897 targets nucleotides 4940 to 5137 of HGSV RNA1, with an expected amplification product of $198 \mathrm{bp}$.

Eleven citrus trees within $\approx 50 \mathrm{~m}$ of tree WAI 1-1 were inspected for the presence of citrus leprosis symptoms. Three leaves from each tree were selected and assayed for the presence of HGSV using the RT-PCR protocol described above with primers 896/897.

To determine whether HGSV is systemic in C. volkameriana, two asymptomatic leaves taken from an air-layered propagation of tree WAI 1-1 were assayed. This air-layered plant did have foliar symptoms in existing leaves but the new growth was asymptomatic.

Because there appear to be similarities between HGSV and CiLV-C, and symptoms of hibiscus green spot have been observed in Hawaiian hibiscus plants (Fig. 1), symptomatic leaf tissues taken from seven $H$. arnottianus plants, as well as four healthy control leaves from four of these plants, were also assayed for the presence of HGSV using the RT-PCR protocol described above with primers 896/897. For these hibiscus samples, total RNA was isolated using an RNeasy Plant Mini Kit (Qiagen, Valencia, CA) following the manufacturer's directions.

Electron microscopy. $C$. volkameriana leaf pieces of $\approx 1$ by $2 \mathrm{~mm}$ excised from symptomatic leaves and healthy controls were fixed for 1 to $2 \mathrm{~h}$ in $0.1 \mathrm{M}$ sodium cacodylate ( $\mathrm{pH} 7.4$ ) containing $2 \%$ glutaraldehyde and $2 \%$ paraformaldehyde, followed by two 20-min washes in $0.1 \mathrm{M}$ sodium cacodylate solution. Leaf pieces were postfixed in $0.1 \mathrm{M}$ sodium cacodylate solution containing $1 \%$ osmium tetroxide for $1.5 \mathrm{~h}$. The leaf pieces were then dehydrated in a graded ethanol series followed by three 10-min exposures to propylene oxide. The leaf pieces were embedded with LX-112 epoxy resin (Ladd Research, Williston, VT) following the manufacturer's instructions. Sections were stained with uranyl acetate and lead citrate and viewed with a LEO 912 transmission electron microscope (Carl Zeiss, Thornwood, NY).

Double-stranded RNA isolation and cloning. Double-stranded (ds)RNAs were isolated from leaf and bark tissue of $C$. volkameriana tree WAI 1-1 and H. arnottianus leaves with ringspot symptoms as described (9), and cDNA libraries were generated from the dsRNAs (20). Clones were sequenced at the Advanced Studies of Genomics, Proteomics, and Bioinformatics laboratory at the University of Hawaii. For the library derived from the $C$. volkameriana dsRNAs, contiguous sequences (contigs) were assembled using CAP3 (10), and gaps between contigs were filled using RT-PCR and contig-specific primers designed to amplify these gaps. Amplification products were ligated into pGEM-T Easy (Promega Crop.) and sequenced as described above. The termini were obtained by dsRNA polyadenylation or RLM-rapid amplification of cDNA ends (RACE). Yeast polyA polymerase (USB, Cleveland, OH) was used to polyadenylate dsRNA following the manufacturer's directions. Primer 900 (5'-CACTCCC ATTATCCAGG []$_{16} 3^{\prime}$ ) initiated first-strand synthesis, and the resulting complementary (c)DNA was amplified using primer 900 and a virus-specific primer that annealed near the desired terminus. To identify termini with existing poly(A) tails, cDNAs were also synthesized with primer 900 using unmodified dsRNA prior to amplification. The RLM-RACE procedure of Coutts and Liveratos (7) was modified by using primer 280 (5'-CAGTTT GTTCATGCGCGC-3') as Oligo1rev and primer 467 (5'-GCGCG

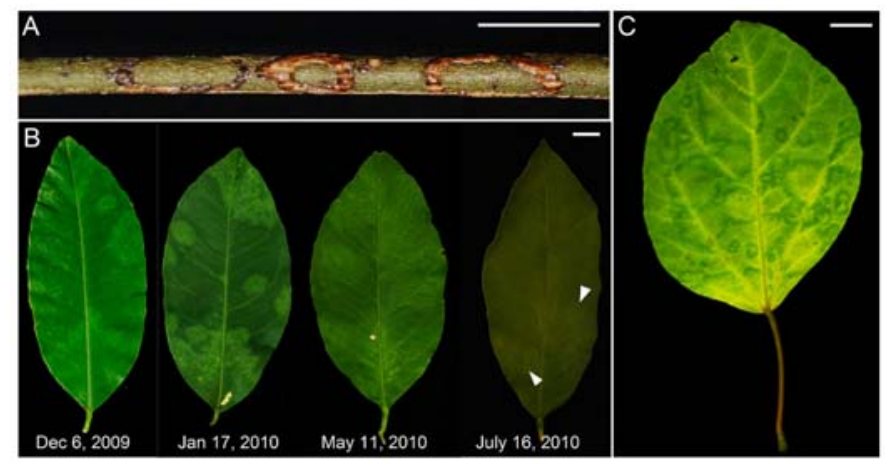

Fig. 1. Citrus leprosis-like symptoms displayed in tree WAI 1-1 include A, raised oval lesions on bark and $\mathbf{B}$, chlorotic lesions on leaves. Foliar symptoms were most prominent during the coolest months and attenuated as the seasonal temperatures increased (arrowheads). C, Hibiscus green spot symptoms in Hibiscus arnottianus. Bars in $\mathrm{A}, \mathrm{B}$, and $\mathrm{C}=1 \mathrm{~cm}$. 
CATGAACAAACTG-3') as Oligo2for. Amplification products were cloned and sequenced as described above, with at least five clones sequenced for each terminus.

Northern hybridization. dsRNAs isolated from leaf and bark tissue of WAI 1-1 were resolved in a $1 \%$ (wt/vol) agarose gel and electrophoretically transferred to a positively charged nylon membrane (Roche, Indianapolis, IN) by capillary transfer. Digoxigenin (DIG)-labeled (Roche) probes were obtained by PCR using clones derived from the dsRNA as template. Prehybridization and hybridization of the membrane was performed in PerfectHyb Plus hybridization buffer (Sigma-Aldrich) at $68^{\circ} \mathrm{C}$ for $30 \mathrm{~min}$ and overnight, respectively. Subsequent washes, antibody binding, and CSPD chemiluminescent detection were performed following the DIG manufacturer's instructions.

Phylogenetic analyses. The amino acid sequences of the RdRp domain of RNA1 was used to infer the phylogenetic relationship between HGSV and select viruses possessing an RdRp2-type domain. Sequences were aligned using ClustalX 2.0.12 (17) and phylogenetic trees were generated using neighbor-joining (NJ), maximum likelihood (ML), and Bayesian analyses. ClustalX 2.0.12 was used to create and bootstrap the NJ tree, PAUP v4.0b (Sinauer Associates, Inc., Sunderland, MA) was used for the ML algorithm, and MrBayes v3.1.1 (11,26) was used to create trees using a Bayesian algorithm. With MrBayes v3.1.1, the fixed-rate amino acid mixed model that allows model switching during the analysis was used with 400,000 to 500,000 generations and sampling every 100 generations. Trees were viewed with TreeView v1.6.6 (23).

\section{RESULTS}

CiLV-C-specific detection assays. Citrus leprosis-like symptoms were observed on the $C$. volkameriana tree WAI 1-1 growing on the island of Oahu, Hawaii. To determine whether the most common causal agent of the disease, CiLV-C, was present in this tree, a DASI-ELISA detection assay was employed. After a 60 -min incubation, the absorbance values at $405 \mathrm{~nm}$ of symptomatic tissues ranged from $0.037 \pm 0.005$ to $0.058 \pm 0.018$, and were less than those of a healthy control $(0.103 \pm 0.004)$. In contrast, an expressed CiLV-C protein at the recommended dilution of 1:500 had an absorbance value of $1.033 \pm 0.019$.

RT-PCR assays that detect the MP gene and replicase gene of CiLV-C (18) were also used to assess the presence of this virus. Both of these assays, however, produced negative results in both tree WAI 1-1 and healthy seedling controls (Fig. 2). Taken together, these results indicate that the causal agent of the symptoms observed in tree WAI 1-1 is distinct from CiLV-C.

Electron microscopy. Symptomatic and asymptomatic leaf sections were examined for the presence and cellular localization of virus-like particles (VLPs) by transmission electron micro-

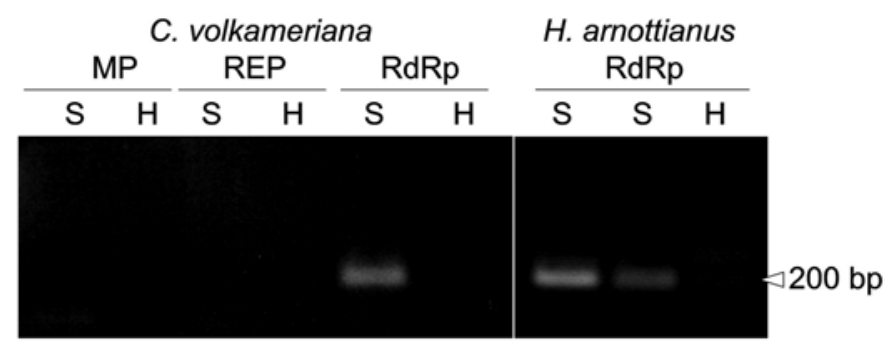

Fig. 2. Detection of Hibiscus green spot virus (HGSV) by reverse-transcription polymerase chain reaction. Left panel, symptomatic Citrus volkameriana tissue was negative using Citrus leprosis virus cytoplasmic-type-specific primers (18) but was positive using HGSV-specific primers targeting the RNA-dependent RNA polymerase (RdRp) domain of RNA1 (expected amplification product is $198 \mathrm{bp}$ ). S, symptomatic tissue from tree WAI 1-1; H, healthy seedling. Right panel, detection of HGSV in Hibiscus arnottianus with hibiscus green spot symptoms. S, symptomatic leaf; $\mathrm{H}$, healthy leaf. scopy. Congregations of short, bacilliform VLPs of $\approx 30$ by $50 \mathrm{~nm}$ were observed in the cytoplasm of symptomatic leaf tissues but not the healthy controls (Fig. 3). These VLPs were found in only a small percentage of the cells examined. Rod-shaped particles localized to the nucleus or cytoplasmic viroplasms, which are associated with CiLV-N and CiLV-C infections, respectively $(1,13,24)$, were not observed.

Molecular characterization. dsRNAs were isolated from $10 \mathrm{~g}$ of leaf tissue collected from tree WAI 1-1, a Mexican lime $(C$. aurantifolia) tree infected with CTV, and a greenhouse-grown $C$. volkameriana seedling. High molecular weight dsRNAs of $\approx 20 \mathrm{kbp}$ were present in the CTV-infected trees, presumably representing the 19.3-kbp replicative form of the CTV genome (Fig. 4). dsRNAs of $\approx 8$ and $3 \mathrm{kbp}$ were present in tree WAI 1-1 but not in the CTV-infected Mexican lime or the C. volkameriana seedling (Fig. 4). These dsRNAs were gel purified and their complete sequence determined from cloned cDNA. Excluding the poly-A tail, the 8,354-bp RNA1 molecule (GenBank accession HQ852052) possessed a large open reading frame (ORF) on the positive strand that putatively encoded a 2,645-amino-acid, $273-\mathrm{kDa}$ protein. This putative protein contained methyltransferase (pf01660; amino acid residues 129 to 533), cysteine protease (pf02338; amino acid residues 717 to 829), helicase (pf01443; amino acid residues 1,610 to 1,896), and RdRp2 (pf00978; amino acid residues 2,126 to 2,565 ) domains (Fig. 4). The methyltransferase, helicase, and $\mathrm{RdRp}$ domains were 38,37 , and $48 \%$ identical to those of CiLV-C, respectively.

The 3-kbp dsRNA band was composed of two similarly sized molecules. Excluding the polyA tail, RNA2 was 3,169 bp in length and possessed four ORFs which, from the $5^{\prime}$ to $3^{\prime}$ end, putatively encoded proteins with molecular masses of 50, 39, 9, and $6 \mathrm{kDa}$ (Fig. 4) (GenBank HQ852053). The 50-kDa protein was unrelated to other proteins present in GenBank. The 39-, 9-, and 6-kDa proteins, however, had characteristics of triple gene block (TGB)p1, TGBp2, and TGBp3 of a TGB plant virus movement module $(22,29)$. The $39-\mathrm{kDa}$ protein possessed the seven typical motifs of viral helicases but lacked a conspicuous stretch of positively charged residues found in the $\mathrm{N}$-terminal region of some other TGBp1s (22). The 9-kDa protein possessed two hydrophobic transmembrane regions and some signature residues of TGBp2. The 6-kDa protein possessed a single hydrophobic transmembrane region, typical of some TGBp3s.

Excluding the polyA tail, RNA3 was 3,113 bp in length and possessed three ORFs which, from $5^{\prime}$ to $3^{\prime}$, putatively encoded proteins of 33, 29, and $23 \mathrm{kDa}$ (GenBank HQ852054). The 33and $29-\mathrm{kDa}$ proteins had only low homology to other sequences

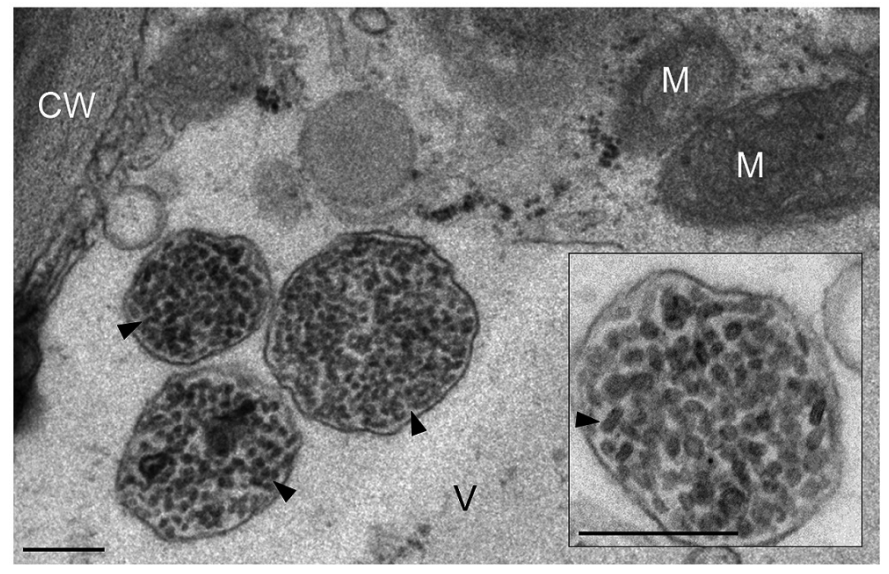

Fig. 3. Transmission electron micrograph of a Hibiscus green spot virusinfected Citrus volkameriana leaf cell. Arrowheads indicate aggregates containing virus-like particles (VLPs). Inset is a magnification of an aggregate with the arrowhead indicating a VLP. CW, cell wall; M, mitochondrion; V, vacuole. Bar $=250 \mathrm{~nm}$. 
deposited in GenBank, none of which were of viral origin. The $23-\mathrm{kDa}$ protein, however, was an ortholog of CiLV-C p24, with the two proteins being $26 \%$ identical.

The 5'-untranslated region of RNA1, RNA2, and RNA 3 began with the sequence $5^{\prime}-\mathrm{CAU}(\mathrm{A})_{3-4} \mathrm{U} \ldots 3^{\prime}$. One of the six clones derived from RNA1 indicated that the 5' terminus was 5'CUUCAUAAAU... $3^{\prime}$ but, because these three additional nucleotide residues were not observed in any other clones, they were considered an aberration. The 5'- and 3'-untranslated regions of the RNAs were $\mathrm{G}+\mathrm{U}$ rich (61 to $73 \%$ ), predominantly due to repeats of the nucleotide pattern $\mathrm{G}(\mathrm{U})_{2-5}$.

To confirm the size of RNA1, RNA2, and RNA3, dsRNAs isolated from tree WAI 1-1 were exposed to DIG-labeled probes corresponding to each of the molecules. The probes corresponding to RNA1, RNA2, and RNA3 hybridized to the 8-, 3-, and 3-kbp dsRNAs present in the WAI 1-1 sample, respectively (Fig. 4). These results validated the sequence data and confirmed that two distinct $\approx 3 \mathrm{kbp}$ dsRNAs were present in tree WAI 1-1.

Phylogenetic analyses. The phylogenetic relationships between HGSV and other viruses with RdRp2 domains were inferred using distance-based (NJ) and character-based (ML and Bayesian) algorithms. The trees generated from all algorithms were essentially identical (Fig. 5; data not shown). HGSV was placed in the same clade as CiLV-C in the genus Cilevirus. All other viruses used in the analyses grouped with their respective genus or family. The point of divergence between HGSV and CiLV-C is similar to that of the genus Tobravirus from the genera Furovirus and Pomovirus (Fig. 5).

Detection assay and small scale survey for HGSV. An RTPCR-based assay was developed for detection of HGSV based on the sequence of RNA1. Primers 896 and 897 amplified a 198-bp product from leaves taken from tree WAI 1-1 but not from leaves taken from a greenhouse-grown $C$. volkameriana seedling (Fig. 2 ). Eleven other citrus trees within $\approx 50 \mathrm{~m}$ of tree WAI $1-1$ were screened for the presence of citrus leprosis-like symptoms and were assayed for the presence of HGSV using RT-PCR. None of these 11 trees displayed citrus leprosis-like symptoms (data not shown). Only tree WAI 1-1, which displayed symptoms similar to citrus leprosis, was positive for HGSV.

Two asymptomatic leaves from an air-layered plant derived from tree WAI 1-1 were also assayed for the presence of HGSV.
The RT-PCR assay indicated that both leaves were negative for the virus (data not shown).

HGSV in $\boldsymbol{H}$. arnottianus. Leaves from seven $H$. arnottianus plants with hibiscus green spot symptoms and four asymptomatic leaves from four of these plants were assayed for the presence of HGSV using RT-PCR. Six of the seven symptomatic leaves were positive with this assay, whereas all of the asymptomatic leaves were negative (Fig. 2; data not shown). The green spot of the symptomatic sample which tested negative was small (3 to $4 \mathrm{~mm}$ in diameter) compared with most of the symptomatic samples that tested positive ( $>10 \mathrm{~mm}$ in diameter). The 198-bp amplicon from one of the symptomatic leaves was sequenced and found to be $99 \%$ identical to HGSV from C. volkameriana. dsRNAs $\approx 8$ and $3 \mathrm{kbp}$ in size were isolated from $10 \mathrm{~g}$ of symptomatic tissue (Fig. 4) and used as template for a cDNA library. In all, 10 clones from this library, 340 to 579 bp in length, were sequenced; 5 clones mapped to HGSV RNA1, 3 clones to HGSV RNA2, and 2 clones to HGSV RNA3. All clones were $>98 \%$ identical to the HGSV strain present in C. volkameriana (data not shown).

\section{DISCUSSION}

This study documents the presence of a new citrus leprosis-like disease in Hawaii, and characterizes a virus in symptomatic tissue. The disease observed in Hawaii is similar to citrus leprosis, with raised, circular, rusty-orange-colored lesions on bark tissue, and foliar symptoms were also similar to the early stages of citrus leprosis. Foliar symptoms were also most pronounced during the cooler winter months, an affect which has also been observed for citrus leprosis in Brazil (24). The virus characterized in symptomatic $C$. volkameriana tissue was also present in $H$. arnottianus leaves with symptoms of hibiscus green spot but not asymptomatic controls. One symptomatic $H$. arnottianus leaf tested negative using the RT-PCR assay; however, the symptomatic area was considerably smaller in this sample compared with most of the others, and may have been below the detection level of the assay. The possibility of sequence variation in different strains of HGSV at the RT-PCR primer binding sites, however, may also explain this result. Hibiscus green spot has been associated with HGSV, a cytoplasmic, nonsystemic, bacilliform virus that is transmitted by Brevipalpus phoenicis $(12,14)$. Both C. volkameri-

A

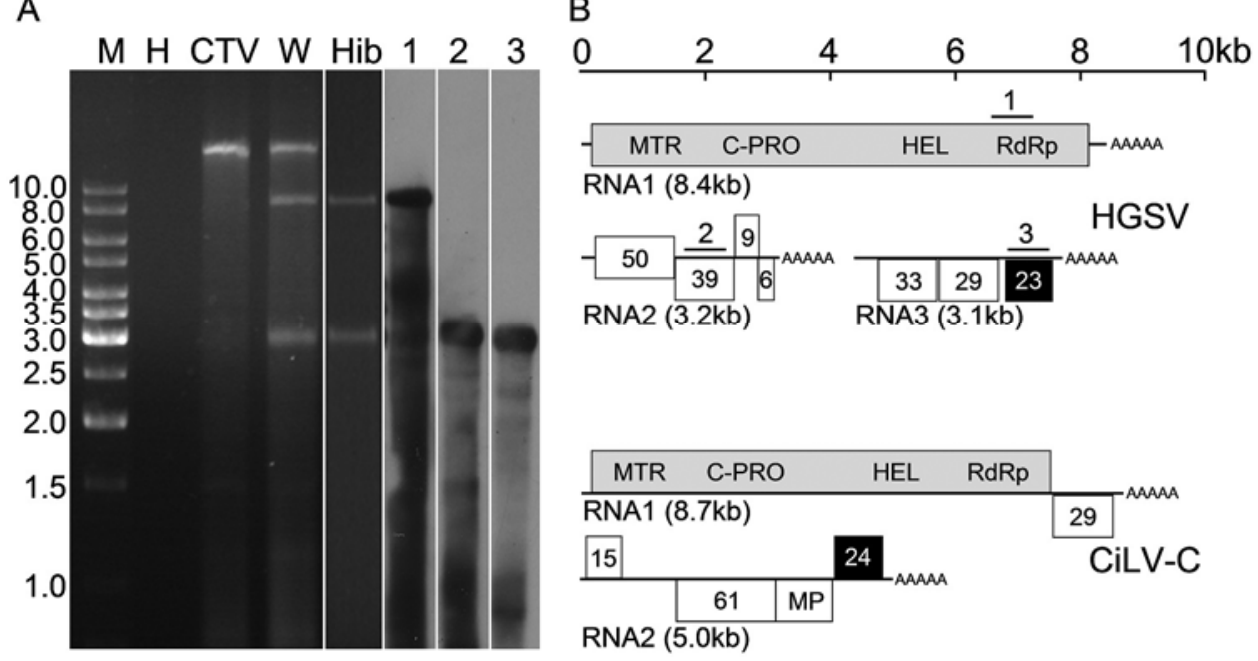

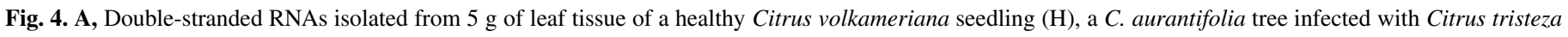

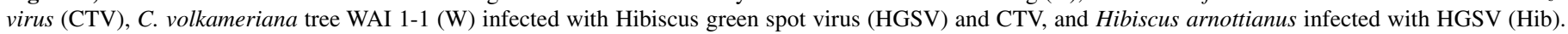

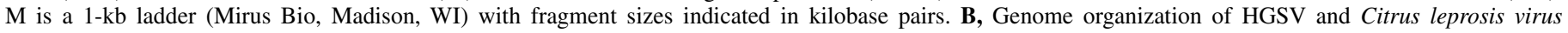

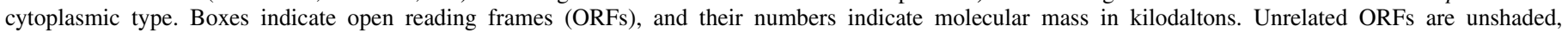

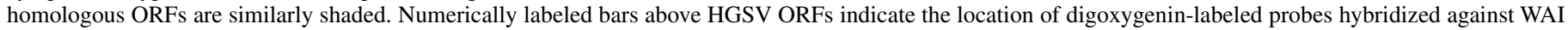

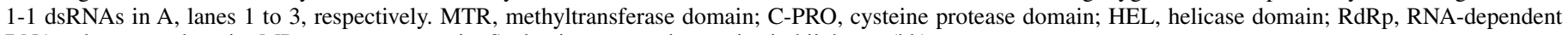
RNA polymerase domain; MP, movement protein. Scale gives approximate size in kilobases $(\mathrm{kb})$. 
ana tree WAI 1-1 and the H. arnottianus trees displaying hibiscus green spot were infested with mites of the genus Brevipalpus. In addition, the virus identified in this study did not appear to move systemically in either $C$. volkameriana or H. arnottianus. Based on this evidence, we contend the virus characterized in this study is HGSV.

Sweet orange and mandarin varieties are reportedly the most susceptible to citrus leprosis (24). In this study, the symptomatic host was a Volkamer lemon tree, a species that has not been previously associated with citrus leprosis. This suggests that HGSV has a different or expanded host range compared with CiLV-C, and it is important to determine whether HGSV causes citrus leprosis-like symptoms in economically important citrus such as sweet orange and mandarin. Tree WAI 1-1, however, is also infected with CTV and has symptoms of woody gall, putatively caused by a Luteovirus sp. $(6,21)$. Mixed plant virus infections often produce unexpected or synergistic reactions in plant hosts; this possibility should be considered when correlating symptoms with disease etiology. The disease described in this study also resembles citrus zonate chlorosis, a putative viral disease of sweet orange found in the coastal regions of Brazil (3). Like citrus leprosis, citrus zonate chlorosis is spread by mites of the genus Brevipalpus (27). To date, no virus associated with this disease has been characterized. The HGSV-specific RT-PCR assay developed in this study will be useful to determine whether citrus zonate chlorosis is caused by HGSV.

HGSV shares several features with CiLV-C, the most prevalent causal agent of citrus leprosis in South America. CiLV-C virions and the VLPs identified in this study are both localized to the cytoplasm and have similar architectures, although the 30-by50-nm VLPs are smaller than the 50-by-150-nm CiLV-C virions. RNA1 of both HGSV and CiLV-C encode large polyproteins that are presumably involved in viral replication. Based on sequence similarity, these polyproteins are clearly orthologs, which is supported by the close phylogenetic relationship between the RdRp domains of these polyproteins compared with other viruses possessing this domain. HGSV and CiLV-C possess 3 '-terminal ORFs encoding orthologous 23- or 24-kDa proteins on RNA3 and RNA2, respectively. The function of these two proteins is unknown.

There are also obvious differences between HGSV and CiLV-C. HGSV is tripartite, whereas CiLV-C is bipartite. CiLV-C possesses an ORF at the $3^{\prime}$ terminus of RNA1 which encodes a highly expressed $29-\mathrm{kDa}$ protein associated with cytoplasmic inclusion bodies in CiLV-C-infected cells (R. F. Lee, personal communication). The CiLV-C-specific antibodies used in this study were raised against this p29 antigen. The lack of a p29 homolog in HGSV may explain the lack of viroplasms or inclusion bodies observed in HGSV-infected cells, as well as the negative results from DAS-ELISA assays.

CiLV-C encodes a putative MP on RNA2 that is similar to the 3A class of viral MPs (pf00803) (19). Such an MP is lacking in the genome of HGSV. However, the 39-, 9-, and 6-kDa proteins putatively encoded by RNA2 of HGSV have striking similarities to TGBp1, TGBp2, and TGBp3, respectively $(22,29)$. To date, the TGB movement machinery has only been found in members of the helical plant virus families Virgaviridae and Flexiviridae. The $\mathrm{TGB}$, however, is not present in all members of these families, because some of these viruses rely on the $30 \mathrm{~K}$ class of proteins for cell-to-cell movement. This heterogeneity in movement machinery also appears to hold true for CiLV-C and HGSV. CiLV$\mathrm{C}$ has a bacilliform virion similar to VLPs identified in tissues infected with HGSV. If HGSV virions are also bacilliform, as suggested in this study and by others $(12,14)$, it would represent the first nonhelical virus to encode a TGB movement module.

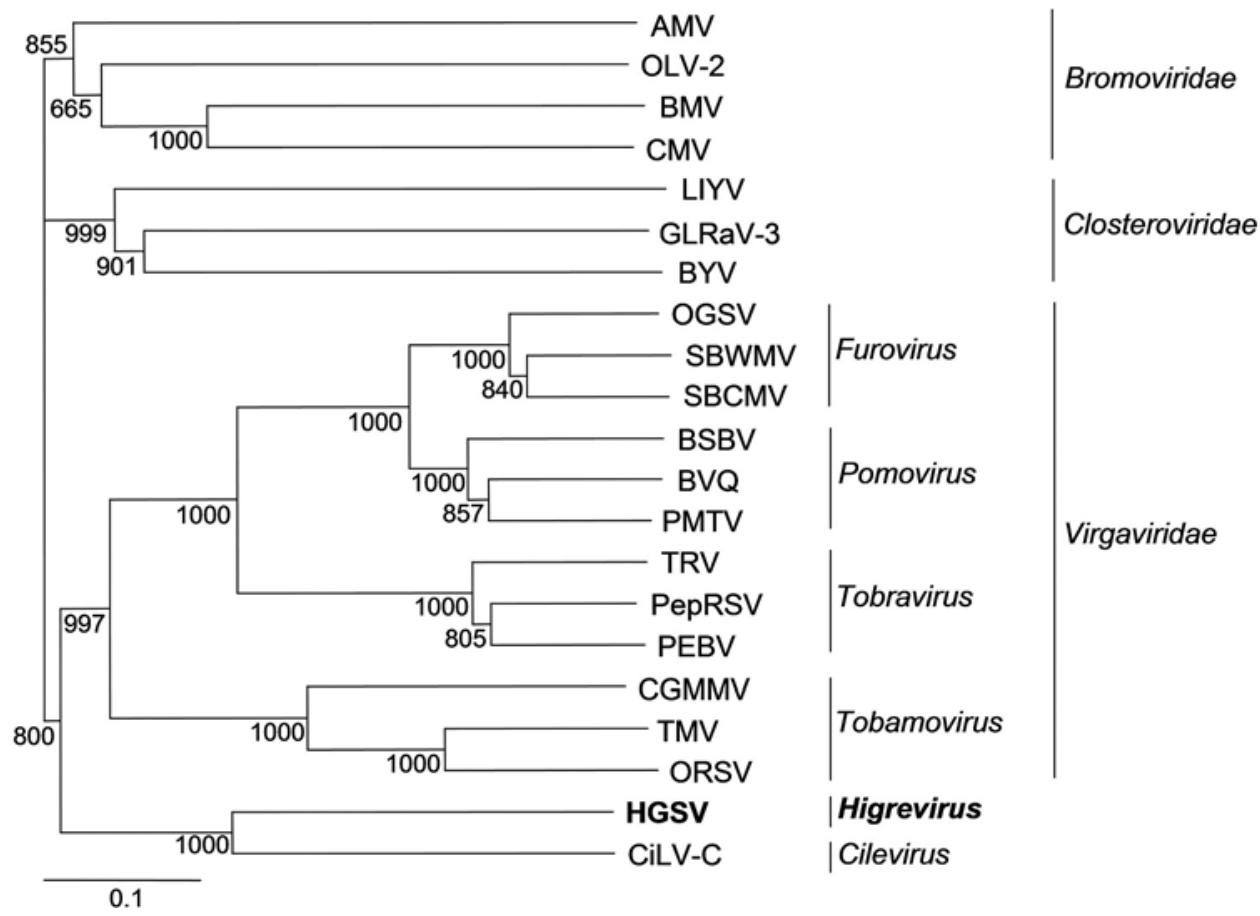

Fig. 5. Phylogenetic relationships between Hibiscus green spot virus (HGSV), of the proposed genus Higrevirus, and other viruses inferred by a neighbor-joining algorithm using the RNA-dependent RNA polymerase domain. Bootstrap values are indicated on branches, and branches with a support of $<600$ of 1,000 replications were collapsed. Scale indicates the number of substitutions for the given branch length. Virus abbreviations; AMV, Alfalfa mosaic virus (GenBank accession P03593); BMV, Brome mosaic virus (P03594); BSBV, Beet soil-borne virus (ABU63612); BVQ, Beet virus Q (NP_612605); BYV, Beet yellows virus (NP_733949); CiLV-C, Citrus leprosis virus-cytoplasmic (YP_654538); CGMMV, Cucumber green mosaic mottle virus (ACP17898); CMV, Cucumber mosaic virus (P16490); GLRaV-3, Grapevine leafroll associated virus 3 (O71189); HGSV, Hibiscus green spot virus (HQ852052); LIYV, Lettuce infectious yellows virus (Q83045); OGSV, Oat golden stripe virus (NP_059510); OLV-2, Olive latent virus 2 (CAA64073); ORSV, Odontoglossum ringspot virus (AAB53794); PEBV, Pea early-browning virus (CAB37343); PepRSV, Pepper ringspot virus (NP_620033); PMTV, Potato mop-top virus (NP_620444); SBCMV, Soil-borne cereal mosaic virus (CAB56599); SBWMV, Soil-borne wheat mosaic virus (NP_049335); TMV, Tobacco mosaic virus (ABN79257); TRV, Tobacco rattle virus (NP_620444). 
HGSV and CiLV-C, the type member of the newly formed genus Cilevirus $(2,19)$, represent two related viruses that are distinct from members of other viral taxa. The substantial differences between the genomes of HGSV and CiLV-C and the phylogenetic distance between these two viruses, however, make it difficult to include HGSV in the genus Cilevirus and, instead, warrant the creation of a new viral genus. Therefore, we propose the creation of the virus genus Higrevirus with Hibiscus green spot virus as the type member. The characterization of additional viruses related to HGSV and CiLV-C will help to further resolve the classification of this emerging group of viruses.

\section{ACKNOWLEDGMENTS}

This research was funded, in part, by a specific cooperative grant agreement number 58-5320-5-785 between the United States Department of Agriculture-Agricultural Research Service Pacific Basin Agricultural Research Center and the University of Hawaii at Manoa. We thank R. Lee for the generous gift of the antisera used in this study; C. Childers, J. C. Rodrigues, and E. W. Kitajima for their helpful discussions; and T. Carvalho for technical assistance with electron microscopy.

\section{LITERATURE CITED}

1. Bastianel, M., Novelli, V. M., Kitajima, E. W., Kubo, K. S., Bassanezi, R. B., Machado, M. A., and Freitas-Astúa, J. 2010. Citrus leprosis: Centennial of an unusual mite-virus pathosystem. Plant Dis. 94:284-292.

2. Carstens, E. B. 2010. Ratification vote on taxonomic proposals to the International Committee on Taxonomy of Viruses (2009). Arch. Virol. $155: 133-146$

3. Chagas, C. M. 2000. Leprosis and zonate chlorosis. Pages 57-58 in: Compendium of Citrus Diseases, Second Edition. L. W. Timmer, S. M., Garnsey, and J. H. Graham, eds. American Phytopathological Society Press, St. Paul, MN.

4. Chagas, C. M., Rossetti, V. V., and Chiavegato, L. G. 1984. Effectiveness of the different life cycles stages of Brevipalpus phoenicis Geijskes in leprosis transmission. Pages 211-214 in: Proc. 9th Conf. Int. Org. Citrus Virol. S. M. Garnsey, L. W. Timmer, and J. A. Dodds, eds. IOCV, Riverside, CA.

5. Childers, C. C., Rodrigues, J. C. V., Derrick, K. S., Achor, D. S., French, J. V., Welbourn, W. C., Ochoa, R., and Kitajima, E. W. 2003. Citrus leprosis and its status in Florida and Texas: Past and present. Exp. Appl. Acarol. 30:181-202.

6. Clark, C. C., and da Graça, J. V. 2000. Detection of Citrus vein enation virus using Cereal yellow dwarf virus ELISA kits. Pages 357-359 in: Proc. 14th Conf. Int. Org. Citrus Virol. J. V. da Graça, R. F. Lee, and R. K. Yokomi, eds. IOCV, Riverside, CA.

7. Coutts, R. H. A., and Livieratos, I. C. 2003. A rapid method for sequencing the 5'- and 3'-termini of double-stranded RNA viral templates using RLM-RACE. J. Phytopathol. 151:525-527.

8. Dominguez, F. S., Bernal, A., Childers, C. C., and Kitajima, E. W. 2001. First report of Citrus leprosis virus in Panama. Plant Dis. 85:228.

9. Hu, J. S., Gonsalves, A., Sether, D., and Ullman, D. E. 1993. Detection of pineapple closterovirus, a possible cause of mealybug wilt of pineapple. Acta Hortic. 334:411-416.

10. Huang, X., and Madan, A. 1999. CAP:3 A DNA sequence assembly program. Genome Res. 9:868-877.
11. Huelsenbeck, J. P., and Ronquist, F. 2001. MRBAYES: Bayesian inference of phylogeny. Bioinformatics 17:754-755.

12. Kitajima, E. W., Chagas, C. M., and Rodrigues, J. C. V. 2003. Brevipalpus-transmitted plant virus and virus-like diseases: Cytopathology and some recent cases. Exp. Appl. Acarol. 30:135-160.

13. Kitajima, E. W., Müller, G. W., Costa, A. S., and Yuki, V. 1972. Short rodlike particles associated with citrus leprosis. Virology 50:254-258.

14. Kitajima, E. W., Rodrigues, J. C. V., and Freitas-Astua, J. 2010. An annotated list of ornamentals naturally found infected by Brevipalpus mite-transmitted viruses. Sci. Agric. 67:348-371.

15. Knorr, L., C. 1973. Citrus Diseases and Disorders. The University Presses of Florida, Gainesville.

16. Knorr, L. C., Denmark, H. A., and Burnett, H. C. 1968. Occurrence of Brevipalpus mites, leprosis, and false leprosis on citrus in Florida. Fla. Entomol. 51:11-17.

17. Larkin, M. A., Blackshields, G., Brown, N. P., Chenna, R., McGettigan, P. A., McWilliam, H., Valentin, F., Wallace, I. M., Wilm, A., Lopez, R., Thompson, J. D., Gibson, T. J., and Higgins, D. G. 2007. Clustal W and Clustal X version 2.0. Bioinformatics 23:2947-2948.

18. Locali, E. C., Freitas-Astua, J., de Souza, A. A., Takita, M. A., AstuaMonge, G., Antonioli, R., Kitajima, E. W., and Machado, M. A. 2003. Development of a molecular tool for the diagnosis of leprosis, a major threat to citrus production in the Americas. Plant Dis. 87:1317-1321.

19. Locali-Fabris, E. C., Freitas-Astúa, J., Souza, A. A., Takita, M. A., AstúaMonge, G., Antonioli-Luizon, R., Rodrigues, V., Targon, M. L. P. N., and Machado, M. A. 2006. Complete nucleotide sequence, genomic organization and phylogenetic analysis of Citrus leprosis virus cytoplasmic type. J. Gen. Virol. 87:2721-2729.

20. Melzer, M. J., Borth, W. B., Sether, D. M., Ferreira, S., Gonsalves, D., and $\mathrm{Hu}$, J. S. 2010. Genetic diversity and evidence for recent modular recombination in Hawaiian Citrus tristeza virus. Virus Genes 40:111-118.

21. Melzer, M. J., Borth, W. B., Zee, F., Hilf, M. E., Garnsey, S. M., and Hu, J. S. 2005. Incidence, distribution, and diversity of Citrus tristeza virus in the Hawaiian Islands. Pages 179-186 in: Proc. 16th Conf. Int. Org. Citrus Virol. M. E. Hilf, N. Duran-Vila, and M. A. Rocha-Peña, eds. IOCV, Riverside, CA.

22. Morozov, S. Y., and Solovyev, A. G. 2003. Triple gene block: Modular design of a multifunctional machine for plant virus movement. J. Gen. Virol. 84:1351-1366.

23. Page, R. D. M. 1996. TREEVIEW: An application to display phylogenetic trees on personal computers. Comput. Appl. Biosci. 12:357-358.

24. Rodrigues, J. C. V., Kitajima, E. W., Childers, C. C., and Chagas, C. M. 2003. Citrus leprosis virus vectored by Brevipalpus phoenicis (Acari: Tenuipalpidae) on citrus in Brazil. Exp. Appl. Acarol. 30:161-179.

25. Rodrigues, J. C. V., Zuniga Reyes, J. A., Achor, D. S., Childers, C. C., and Kitajima, E. W. 2007. Occurrence and distribution of Citrus leprosis virus in Honduras. Plant Pathol. 56:344.

26. Ronquist, F., and Huelsenbeck, J. P. 2003. MRBAYES 3: Bayesian phylogenetic inference under mixed models. Bioinformatics 19:1572-1574

27. Rossetti, V., Lasca, C. C., and Negretti, S. 1969. New developments regarding leprosis and zonate chlorosis of citrus. Pages 1453-1456 in: Proc. 1st Int. Citrus Symp. H. D. Chapman, ed. University of California, Riverside.

28. Stewart, C. N., Jr., and Via, L. E. 1993. A rapid CTAB DNA isolation technique useful for RAPD fingerprinting and other PCR applications. Biotechniques 14:748-750.

29. Verchot-Lubicz, J., Torrance, L., Solovyev, A. G., Morozov, S. Y., Jackson, A. O., and Gilmer, D. 2010. Varied movement strategies employed by triple gene block-encoding viruses. Mol. Plant-Microbe Interact. 23:1231-1247. 